\title{
Perempuan Pada Cerita Rakyat Jepang dan Indonesia: Analisis Komparatif dengan Pendekatan Feminisme
}

\author{
Nina Alia Ariefa ${ }^{1}$, Mutiawanthi ${ }^{2}$ \\ ${ }^{1,2}$ Program Studi Sastra Jepang, Fakultas Sastra, Universitas Al Azhar Indonesia, Jl. \\ Sisingamangaraja, Kompleks Masjid Agung Al Azhar, Kebayoran Baru, Jakarta Selatan 12110 \\ Penulis untuk Korespondensi/E-mail: nina_alia@uai.ac.id
}

\begin{abstract}
Abstrak - Penelitian ini bertujuan untuk menemukan citraan perempuan yang terdapat pada cerita rakyat Indonesia dan Jepang, dengan analisis komparatif. Cerita Rakyat yang diperbandingkan terdiri dari tiga cerita rakyat asal Indonesia dan Jepang, yaitu Putri Mandalika Nyale, Putri Pandan Berduri, dan Pangeran Pande Gelang dan Putri Cadasari, serta cerita rakyat Kuro Hime to Kokuryuu, Nezumi no Yomeiri, dan Kaguya Hime. Pendekatan feminisme digunakan untuk menganalisis citraan tokoh-tokoh perempuan berdasarkan aspek fisik, psikis, dan aspek sosial pada masing-masing cerita. Hasilnya yaitu terdapat kesamaan pada citra perempuan dari aspek fisik, yaitu berupa sosok gadis muda yang cantik, pada citra perempuan dari aspek psikis yaitu sosok tokoh perempuan yang tunduk patuh, dan pasrah terhadap nasibnya, dan pada citra perempuan yang menjalani peran dan tanggung jawab dalam kedudukannya sesuai aspek sosial masing-masing tokoh.
\end{abstract}

Kata Kunci - Citra perempuan, Feminisme, Cerita rakyat, Indonesia, Jepang.

Abstract - This research aims to find images of women in Indonesian and Japanese folklore, through comparative analysis. The main data are six folklores consist of three folklores from Indonesia (Putri Mandalika Nyale, Putri Pandan Berduri, and Pangeran Pande Gelang dan Putri Cadasari) and three folklores from Japan (Kuro Hime to Kokuryuu, Nezumi no Yomeiri and Kaguya Hime). Feminism approach used to analysis these folklores by observing the images of female characters based on the physical, psychological, and sosial aspect of each story. The results show that there are similarities in the image of female characters from the physical aspect which are beautiful young girl figures, psycological aspect which are obedient women and resigned to their fate, and in the image of women who live their roles and responsibilities in their positions according to the social aspect of each character.

Keywords - Woman images, Feminism, Folklore, Indonesia, Japan.

\section{PENDAHULUAN}

$\mathrm{S}^{\mathrm{a} a \mathrm{a}}$ astra lisan, sebagai bagian dari sastra tradisional, merupakan kekayaan budaya suatu bangsa, dan wujud warisan masa lalu yang berasal dari leluhur. Sastra lisan meliputi di antaranya adalah pepatah, peribahasa, dan folklor. Dalam sastra lisan terkandung muatan kearifan lokal bangsa tersebut, yang berfungsi sebagai refleksi masyarakat penuturnya. Kearifan lokal dapat didefinisikan sebagai suatu kekayaan budaya lokal yang mengandung kebijakan hidup; pandangan hidup (way of life) yang mengakomodasi kebijakan (wisdom) dan kearifan hidup. Kearifan lokal dapat pula dipandang sebagai identitas bangsa yang menuntun masyarakatnya ke dalam pencapaian kemajuan dan keunggulan, etos kerja, serta keseimbangan dan keharmonisan alam dan sosial. Kearifan lokal yang terkandung dalam sastra lisan, diajarkan secara turun-temurun, dan diwariskan dari generasi ke generasi, hingga wujudnya tetap ada dan dapat kita rasakan hingga masa kini.

Sebagai bagian dari sastra lisan, folklor memiliki peran dalam penyebaran nilai-nilai kearifan lokal dari kolektif pendukungnya. 
Selain hal tersebut, gambaran mengenai bagaimana suatu kolektif mendefinisikan diri mereka sendiri dapat digali pula melalui gambaran interaksi sosial yang terdapat dalam suatu cerita rakyat.

Salah satu pendekatan yang dapat digunakan dalam telaah mengenai folklor adalah pendekatan feminisme. Menurut Djajanegara (2000: 27), di antara ragam kritik sastra yang muncul adalah kritik sastra feminis-idiologis, yaitu kritik sastra feminis yang melibatkan perempuan, khususnya kaum feminis sebagai pembaca [1]. Yang menjadi pusat perhatian pembaca perempuan adalah citra serta stereotipe perempuan dalam karya sastra. Pembahasan mengenai citra perempuan dalam kesusastraan pada saat ini mendapat perhatian yang cukup besar. Pembicaraan tentang perempuan sebagai salah satu anggota kelompok masyarakat merupakan kajian sastra yang cukup sering dibicarakan. Hal ini berkaitan dengan perubahan dalam memandang masalah ini sesuai perubahan nilai-nilai dan moralitas mereka yang memberi penilaian. Sekalipun nantinya terdapat perbedaan atau persepsi dalam penilaian, hal itu merupakan konsekuensi dari nilai-nilai yang dianut. Perkembangan atau perubahan nilai-nilai dalam masyarakat ini sedikit banyak menyebabkan perubahan dalam menampilkan tokoh-tokoh dalam karya sastra, khususnya tokoh perempuan. Bagaimanapun juga karya sastra yang mencerminkan selera dan aspirasi suatu kelompok masyarakat tertentu merupakan gejala yang selalu ada pada setiap zaman, sepanjang sejarah kesusasteraan. Gejala tersebut tentu saja dapat mengakibatkan perkembangan yang positif bagi dunia sastra.

Terhadap cerita rakyat, sudah ada anggapan dari kaum feminis bahwa cerita rakyat bersifat seksis, yaitu mempunyai gambaran yang stereotipe pada para tokoh perempuannya (Norton dalam Buntana, 1998:53). Adanya penggambaran mengenai stereotipe pada tokoh perempuan yang terbungkus dalam balutan budaya dalam cerita rakyat tiap negara menjadi menarik untuk dikaji. Oleh karena itu, fokus penelitian jenis ini terletak pada bagaimana sosok/citra perempuan yang tergambar pada cerita rakyat Indonesia dan Jepang, dengan menggunakan masing-masing tiga buah cerita rakyat asal dua negara tersebut, yaitu Kuro
Hime to Kokuryuu, Nezumi no Yomeiri, dan Kaguya Hime, yang berasal dari Jepang, serta cerita rakyat Putri Pandan Berduri, Putri Mandalika Nyale, dan Pangeran Pande Gelang dan Putri Cadasari, yang berasal dari Indonesia.

Penemuan akan persamaan dan perbedaan citraan perempuan antara tokoh perempuan pada cerita rakyat Indonesia dan Jepang inilah yang menjadi tujuan dalam penelitian ini, dengan perumusan masalah sebagai berikut:

(1) Bagaimana citra perempuan pada cerita rakyat Jepang yang dibandingkan dengan perempuan pada cerita rakyat Indonesia melalui kajian feminisme?

\section{TELAAH KRITIK SASTRA FEMINISME}

Kata citra didefinisikan dalam KBBI (2000: 206) sebagai kesan mental atau bayangan visual yang ditimbulkan oleh suatu kata, frasa, kalimat, dan merupakan unsur yang khas dalam karya prosa dan puisi. Kata citra dalam penelitian ini mengacu pada makna setiap gambaran pikiran. Kata citra diartikan sebagai "kesan mental" atau bayangan visual yang ditimbulkan oleh rangkaian kata, frase, atau kalimat, dan merupakan unsur dasar yang khas dalam karya prosa, puisi, dan drama.

Mengenai istilah 'pencitraan', Pradopo (2002: 795) mendefinisikan sebagai gambarangambaran dalam pikiran dan bahasa yang menggambarkannya, gambaran pikiran yang terdapat dalam citra merupakan efek dalam pikiran yang sangat menyerupai gambaran yang dihasilkan oleh penangkapan kita terhadap sebuah objek yang dapat dilihat oleh mata, saraf penglihatan, dan daerah-daerah otak yang berhubungan.

Bila kita kaitkan definisi istilah 'pencitraan' tersebut dengan memfokuskan pada kegiatan penelaahan terhadap suatu tokoh dalam karya sastra, maka istilah ini memiliki kaitan yang erat dengan telaah feminisme karena keduanya merepresentasikan pemikiran dan tingkah laku suatu tokoh. Patut dipahami bahwa dasar pemikiran dalam penelitian sastra berspektif feminis adalah upaya pemahaman kedudukan dan peran perempuan seperti tercermin dalam karya sastra (Sugihastuti, 2002:15) [2]. Pencitraan atau citra perempuan adalah 
gambaran yang dimiliki setiap individu mengenai pribadi perempuan. Hal ini juga sejalan dengan pendapat Altenbernd yang terpapar dalam buku Sugihastuti (2000:43) mengenai citraan, yaitu gambar-gambar angan atau pikiran, sedangkan setiap gambar pikiran disebut citra atau imaji. Wujud citra perempuan ini dapat digabungkan dengan aspek fisis, psikis, dan sosial budaya dalam kehidupan perempuan yang melatarbelakangi terbentuknya wujud citra perempuan [2]. Dalam menjaga citranya tersebut, perempuan sebagai individu harus memerankan perannya dengan baik sebagai individu, istri, dan perannya di sosial masyarakat. (Sugihastuti, 2000: 44) [2].

Dengan demikian, citra perempuan terbagi menjadi tiga klasifikasi, yaitu citra diri perempuan berdasarkan aspek fisik, citra diri perempuan dalam aspek psikis, dan citra diri perempuan dalam aspek sosial. Citra perempuan ditinjau dari segi fisik, yaitu gambaran tentang perempuan yang dilihat berdasarkan ciri-ciri fisik atau lahiriah, seperti usia, jenis kelamin, keadaan tubuh, dan ciri muka. Citra fisik perempuan bisa direpresentasikan dengan gambaran fisik perempuan tersebut yang memiliki hubungan terhadap pengembangan tingkah lakunya.

Citra perempuan yang ditinjau dari segi psikis atau kejiwaan, yaitu gambaran tentang perempuan yang dilihat dari segi psikologisnya, seperti mentalitas, ukuran moral, dapat membedakan yang baik dan tidak baik, dan antara yang benar dan salah, temperamen, keinginan, dan perasaan pribadi, sikap dan perilaku, dan IQ (Intelegent Quotion) atau tingkat kecerdasan. Dari citra psikis ini dapat tergambar kekuatan emosional yang dimiliki oleh perempuan dalam sebuah cerita, berupa perasaan, pemikiran, aspirasi, dan keinginannya. Pada aspek psikis ini, citra perempuan juga tidak terlepas dari unsur feminitas. Melalui pencitraan perempuan secara psikis, bisa dilihat bagaimana rasa emosi yang dimiliki perempuan tersebut, rasa penerimaan terhadap hal-hal di sekitar, cinta kasih yang dimiliki dan yang diberikan terhadap sesama atau orang lain, serta bagaimana menjaga potensinya untuk dapat eksis dalam sebuah komunitas.

Sedangkan citra perempuan ditinjau dari segi sosial, yaitu gambaran tentang perempuan yang dilihat berdasarkan ciri-ciri sosiologis yaitu pekerjaan, jabatan, peran dalam masyarakat, tingkat pendidikan, pandangan hidup, agama, kepercayaan, ideologi, bangsa, suku, dan kehidupan pribadi (Satoto, 1994: 45). Menurut Djajanegara (2000:51-53) penelitian tentang citra perempuan yang ditampilkan melalui tokoh-tokoh perempuan di dalam suatu karya sastra tidak dapat dilepaskan dari kedudukan perempuan tersebut dalam masyarakat sebagaimana tercermin dalam karya sastra [1]. Kedudukan perempuan itu sendiri dapat dilihat dalam berbagai kategori seperti sebagai anak, sebagai gadis remaja, sebagai istri, sebagai ibu, ataupun sebagai perempuan pekerja. Satu tokoh perempuan bisa saja menduduki lebih dari satu kategori tersebut. Bersandar pada identitas tokoh perempuan sebagaimana tergambar dalam karya sastra, peneliti sastra berperspektif feminis mencari kedudukan tokoh-tokoh itu di dalam masyarakat untuk selanjutnya dipaparkan pencitraannya berdasarkan gambaran yang yang terdapat dalam karya sastra melalui penokohan tokoh-tokoh tersebut.

Kritik sastra feminisme merupakan studi sastra yang mengarah fokus analisis tentang perempuan (Sofia, 2003:23). Arti kritik sastra feminisme adalah sebuah kritik yang memandang sastra dengan kesadaran khusus akan adanya jenis kelamin yang berhubungan dengan budaya, sastra, dan kehidupan manusia. Jenis kelamin membuat perbedaan di antara semuanya, perbedaan di antara diri pencipta, pembaca, dan faktor luar penulisan dan pembaca sastra.

Kritik sastra feminisme bukan berarti pengkritik perempuan, atau kritik tentang perempuan, juga bukanlah kritik tentang pengarang perempuan. Arti sederhana yang dikandungnya adalah pengkritik memandang sastra dengan kesadaran khusus, kesadaran bahwa ada jenis kelamin yang banyak berhubungan dengan budaya, sastra, dan kehidupan. Membaca sebagai perempuan berarti membaca dengan kesadaran membongkar praduga dan ideologi kekuasaan laki-laki yang androsentris atau patriarki. Perbedaan jenis kelamin pada diri pencipta, pembaca, unsur karya, dan faktor luar itulah yang memengaruhi situasi sistem komunikasi sastra. Penggunaan berbagai teori feminisme diharapkan mampu memberikan pandanganpandangan baru, terutama yang berkaitan 
dengan bagaimana karakter-karakter yang diwakili dalam karya sastra.

\section{METODE PENELITIAN}

Penelitian ini merupakan penelitian dengan metode deskriptif analisis. Langkah kerja penelitian ini diawali dengan pemilihan masing-masing tiga buah cerita rakyat Jepang dan tiga buah cerita rakyat Indonesia sebagai corpus penelitian. Metode penelitian dalam penelitian ini dilakukan dengan empat langkah, yaitu menganalisis struktur cerita, untuk menemukan susunan alur pada masing-masing cerita, melakukan analisis citraan tokoh-tokoh perempuan berdasarkan aspek fisik, psikis, dan aspek sosial, pada masing-masing cerita, perbandingan atau analisis komparatif antara imaji tokoh perempuan pada 3 cerita rakyat Jepang dengan 3 cerita rakyat Indonesia, yang terakhir yaitu penarikan kesimpulan.

\section{PEREMPUAN PADA CERITA RAKYAT JEPANG DAN INDONESIA: ANALISIS KOMPARATIF DENGAN PENDEKATAN FEMINISME}

\section{$\underline{\text { Struktur cerita rakyat Jepang dan Indonesia }}$}

Struktur cerita pada cerita rakyat Kuro Hime to Kokuryuu.

1. Hiduplah seorang putri cantik yang bernama Kuro Hime.

2. Seekor Naga Hitam (Kokuryuu) yang tinggal di pedalaman gunung di daerah Onumaike menyamar menjadi seekor kupu-kupu dan terbang menuju tempat Kuro Hime dan ayahnya yang sedang berjalan-jalan.

3. Kuro Hime tersenyum gembira melihat kecantikan kupu-kupu tersebut.

4. Naga Hitam terpikat dengan senyuman Kuro Hime.

5. Naga Hitam menyamar menjadi seorang samurai muda yang gagah dan pergi berkunjung ke istana sang putri.

6. Naga Hitam menyampaikan keinginannya pada sang raja untuk mendapatkan sang putri.

7. Sang raja menolak permintaan Naga Hitam.
8. Naga Hitam tidak menyerah dan terus mendatangi istana.

9. Di hari yang ke seratus lebih, Naga Hitam menyampaikan ancaman pada sang raja bila ia tetap tidak diperkenankan untuk mendapatkan sang putri.

10. Sang Raja mengajukan syarat pada Naga Hitam

11. Naga Hitam menyetujui syarat yang diminta.

12. Sang raja mengatur rencana untuk menggagalkan Naga Hitam

13. Naga Hitam mengetahui kecurangan raja.

14. Naga Hitam mengamuk dan mulai membuat kerusakan dengan membuat awan yang hitam pekat dan menurunkan hujan deras selama berhari-hari yang menghanyutkan desa-desa sekitar

15. Kuro Hime yang melihat keadaan yang semakin kacau, berlari ke luar istananya dan berteriak menghadap langit sambil berkata bahwa ia akan pergi ke tempat Naga Hitam, dan oleh karenanya ia minta agar bencana yang terjadi dihentikan.

16. Hujan deras berhenti, dan segumpal awan hitam turun dari langit dan menyelubungi tubuh Kuro Hime.

17. Tubuh Kuro Hime lenyap bersama dengan awan hitam tersebut.

\section{Struktur cerita pada cerita rakyat Nezumi no Yomeiri}

1. Suami istri tikus tidak punya anak

2. Suami istri memohon anak pada Dewa

3. Dewa memberi anak perempuan yang cantik

4. Bapak tikus mencarikan jodoh terhebat untuk putrinya

5. Bapak tikus menemui tuan matahari

6. Tuan matahari menolak

7. Bapak tikus menemui tuan awan

8. Tuan awan menolak Bapak tikus menemui tuan angin

9. Tuan angin menolak Bapak tikus menemui tuan tembok

10. Tuan tembok menolak

11. Bapak tikus menikahkan putrinya dengan pemuda tikus tetangganya

\section{Struktur cerita pada cerita rakyat Kaguya Hime}

1. Hiduplah seorang kakek penebang bambu. 
2. Kakek menemukan sebatang bambu yang berkilauan dan membelahnya.

3. Dari dalam bambu muncul seorang bayi yang cantik

4. Kakek membawa bayi perempuan pulang

5. Kakek dan nenek merawat bayi tersebut dengan penuh kasih sayang dan menamakannya Kaguya Hime.

6. Kaguya Hime tumbuh menjadi gadis yang sangat cantik

7. Banyak pria yang datang melamar Kaguya Hime, di antaranya 5 orang pemuda yang sangat gagah.

8. Kaguya Hime tidak berniat menikah, sehingga ia mengajukan syarat pada masing-masing pemuda tersebut untuk mencarikan benda yang langka.

9. Kelima pemuda tersebut pergi mencari benda-benda langka permintaan sang putri, namun tak ada satu pun yang berhasil kembali.

10. Berita tentang kecantikan Kaguya Hime terdengar ke telinga Kaisar

11. Kaisar menginginkan Kaguya Hime untuk menjadi permaisurinya.

12. Kakek dan nenek yang mendengar permintaan Kaisar, sangat senang.

13. Kaguya Hime yang tidak berniat untuk memenuhi permintaan Kaisar, sebenarnya ingin menolaknya namun ia khawatir akan dibunuh.

14. Setiap malam kaguya Hime bersedih sambil menatap bulan.

15. Kakek dan nenek bertanya kepada Kaguya Hime perihal kesedihannya.

16. Kaguya Hime bercerita bahwa ia adalah penghuni bulan, sehingga ia harus kembali ke bulan.

17. Sang kaisar yang mendengar kabar tersebut, memerintahkan para prajurit untuk menjaga rumah Kaguya Hime.

18. Tengah malam para prajurit tiba-tiba tertidur.

19. Kaguya Hime naik ke dalam kereta yang menjemputnya dan pulang ke bulan.

20. Kakek, nenek, serta sang kaisar bersedih atas kepergian Kaguya Hime.

\section{Struktur cerita pada cerita rakyat Putri Pandan Berduri.}

1. Batin Lagoi, kepala suku Sampan, menemukan seorang bayi perempuan di semak pandan.
2. Ia mengangkat anak tersebut dan memberinya nama Putri Pandan Berduri

3. Putri Pandan Berduri tumbuh menjadi gadis yang cantik

4. Batin Lagoi terkesan dengan sikap dan perilaku seorang pemuda yang bernama Jenang Perkasa, yang sebenarnya adalah anak seorang kepala suku dari pulau seberang.

5. Batin Lagoi menawarkan Jenang Perkasa untuk dinikahkan dengan Putri Pandan Berduri.

6. Jenang Perkasa menyetujui tawaran Batin Lagoi

7. Putri Pandan Berduri menikah dengan Jenang Perkasa dan hidup bahagia.

\section{Struktur cerita Pada Cerita Rakyat Putri Mandalika Nyale}

1. Raja Tonjang Beru memimpin negeri Tunjung Bitu dengan bijaksana

2. Permaisuri Dewi Seranting melahirkan seorang bayi yang diberi nama Putri Mandalika

3. Putri Mandalika tumbuh menjadi putri yang cantik dan pesonanya menyebar ke seluruh penjuru daerah

4. Banyak pangeran yang mengajukan lamaran untuk meminang Putri Mandalika

5. Raja dan Permaisuri tidak dapat mengambil keputusan dan menyerahkan keputusannya kepada Putri Mandalika

6. Putri Mandalika bersemedi untuk memperoleh petunjuk.

7. Putri Mandalika meminta para pelamar dan rakyatnya untuk datang ke Pantai Seger Kuta.

8. Putri berdiri di atas sebuah tebing batu untuk mengumumkan keputusannya.

9. Putri berpesan agar kedamaian dan kesejahteraan tetap lestari di negerinya.

10. Putri Mandalika melompat ke dalam laut ditelan ombak yang bergulung-gulung.

11. Raja dan Permaisuri beserta para pangeran serta rakyat bersedih dan mencari jasad Putri Mandalika namun tidak ketemu.

12. Muncul hewan-hewan kecil berwarnawarni di laut yang kini disebut sebagai nyale. 
Struktur cerita pada cerita Rakyat Pangeran Pande Gelang dan Putri Cadasari

1. Putri Arum sedang duduk termenung sedih di sebuah kebun.

2. Seorang kakek tua, Ki Pande, menyapanya dan bertanya mengapa putri tersebut tampak sedih.

3. Keduanya berkenalan.

4. Putri Arum bercerita pada Ki Pande bahwa ia sedang mendapat tekanan dari seorang pangeran bengis dan kejam yang bernama Pangeran Cunihin untuk bersedia menjadi istrinya.

5. Ki Pande memberi Putri Arum saran berupa syarat perkawinan yang akan diajukan kepada Pangeran Cunihin.

6. Ki Pande mengajak Putri Arum ke tempat tinggalnya untuk mengambil alat untuk membuat gelang.

7. Putri Arum pingsan karena kelelahan karena jarak jauh yang ditempuhnya.

8. Putri Arum siuman setelah diminumkan air dari sumber air batu cadas, sehingga namanya berubah menjadi Putri Cadasari.

9. Pangeran Cunihin menemui Putri Cadasari menagih jawaban atas lamarannya.

10. Putri Cadasari mengajukan syarat sesuai dengan saran $\mathrm{Ki}$ Pande, yaitu agar Pangeran Cunihin membuatkan batu keramat yang berlubang.

11. Pangeran Cunihin berhasil membuat lubang pada batu keramat dan meletakkan di pesisir pantai.

12. Secara diam-diam Ki Pande memasangkan gelang besar di lubang batu keramat tersebut.

13. Putri meminta Pangeran Cunihin untuk melewati lubang tersebut agar ia bisa yakin bahwa batu tersebut benar-benar berlubang.

14. Pangeran Cunihin melewati lubang batu keramat.

15. Pangeran Cunihin kesakitan dan berubah menjadi seorang tua renta.

16. Ki Pande berubah menjadi pemuda yang tampan (Pangeran Pande Gelang).

17. Putri Cadasari menikah dengan Pangeran Pande Gelang dan hidup berbahagia.
Analisis citraan Perempuan Pada Cerita Rakyat Jepang

Analisis citraan perempuan pada cerita Kuro Hime to Kokuryuu.

Dalam cerita tersebut, tokoh yang menjadi fokus penelaahan adalah Kuro Hime, seorang putri raja. Dari aspek fisik, Kuro Hime digambarkan sebagai seorang perempuan muda yang sangat cantik, yang karena kecantikannya tersebut, banyak lelaki dari berbagai wilayah yang tertarik dan mengajukan lamaran. Meski topik pada cerita tersebut mengangkat tema seputar Kuro Hime, namun sosok Kuro Hime sendiri tidak banyak dimunculkan. Tokoh yang mendominasi dalam cerita adalah sang raja, ayah Kuro Hime, dan Kokuryuu (Naga Hitam). Kuro Hime muncul di bagian akhir cerita sebagai tokoh yang menghantarkan cerita menuju fase antiklimaks. Karena kemunculannya yang minim, aspek psikis dari Kuro Hime pun tidak banyak tergambar secara langsung pada cerita ini. Ia dikisahkan menyerahkan dirinya kepada sang Naga Hitam dengan syarat agar Sang Naga Hitam menghentikan kekacauan yang ditimbulkannya. Berikut ini adalah kutipannya.

これを見た黒姫は、殿さまがとめるのも聞 かずに外へ走り出すと、大雨が降る空に向 って叫びました。「黒竜よ! 私はあなた のもとへ行きます！ですから、どうか嵐 を鎮めて下さい!」 ...。

Putri yang melihat hal ini, berlari ke luar tanpa menghiraukan larangan dari sang raja. Ia berteriak ke arah langit yang sedang menurunkan hujan deras. "Naga Hitam! Saya akan pergi ke tempatmu! Oleh karena itu, segera hentikan bencana ini!"

Dari penggalan kisah di bagian akhir ini, tampak setidaknya suatu penggambaran dari aspek psikis, bahwa sang putri merupakan sosok perempuan yang rela berkorban demi negerinya. Hal ini berkaitan erat dengan kedudukan Kuro Hime yang memiliki status sosial yang tinggi dalam masyarakatnya. Dengan demikian, hal ini pulalah yang menggambarkan aspek sosial dari sosok Kuro Hime, yaitu sebagai putri dari penguasa negeri. Implikasi dari perannya tersebut, diperoleh penggambaran bahwa ia merupakan sosok yang memiliki kesadaran akan kewajiban yang harus ia jalankan sesuai perannya sebagai putri demi 
keselamatan seluruh negeri. Dari analisis ini tampak bahwa ada kaitan yang sangat erat antara aspek psikis dan aspek sosial dari tokoh Kuro Hime. Selain statusnya sebagai seorang putri, Kuro Hime juga berkedudukan sebagai seorang anak perempuan terhadap ayahnya, sang raja. Sebagai anak perempuan, ayahnya memiliki kekuasan terhadap dirinya. Hal ini ditunjukkan melalui tindakan sang raja yang menolak lamaran Naga Hitam, serta menggunakan putrinya sebagai bagian dari pesyaratan yang diajukannya kepada sang Naga Hitam. Berikut ini adalah kutipannya:

\section{それを聞いて、びっくりした殿さまは、 「いくら立派でも、人間でないものに姫は やれん」と、きっぱりと断わりました。}

Mendengar hal tersebut, sang raja yang terkejut berkata, "Segagah apapun, jika bukan manusia, putriku tidak akan kuserahkan," tolak raja dengan tegas.

そこで殿さまは、黒竜にこんな約束をした のです。「明日、その人間の姿のままで、 わしの馬に遅れずに城のまわりを二十周ま われたら、姫をやろう」

Oleh karena itu sang raja berjanji pada Naga Hitam, "Besok, jika engkau mampu memutari istana ini sebanyak 21 putaran dalam wujud manusia, dan tidak terlambat sedikitpun dari kudaku, maka aku akan serahkan putriku."

Dari kutipan dialog di atas, tampak bahwa sang raja memiliki kuasa atas diri sang putri. Kutipan ini juga memberikan tentang hierarki yang terjadi antara anak perempuan dengan ayahnya, yang berimplikasi pada kewajiban yang harus dipenuhi oleh seorang anak perempuan terhadap ayahnya. Hal ini tampak pada ketiadaan penggambaran unsur psikis dari Kuro Hime mengenai lamaran Naga Hitam serta penolakan ayahnya. Implikasi dari ketiadaan aspek psikis secara langsung dari sosok Kuro Hime pada peristiwa tersebut menunjukkan bahwa adanya penerimaan Kuro Hime terhadap apapun keputusan sang raja mengenai dirinya, yang dengan demikian menggambarkan sikap dari sosok perempuan yang patuh kepada ayahnya.

\section{Analisis citraan perempuan pada cerita rakyat Nezumi no Yomeiri}

Pada cerita ini, yang menjadi tokoh utamanya adalah tuan tikus yang melakukan perjalanan untuk mendapatkan calon suami yang terhebat bagi anak perempuannya. Dari aspek fisik, anak gadis tikus digambarkan sebagai sebagai perempuan muda yang sangat cantik. Kecantikan putrinya menjadi kebanggaan bagi kedua orang tuanya.

「うちの娘は日本一の娘なのだから、何 でも日本一のお婿さんをもらわなければな らない。」と言いました。

"Karena putriku adalah gadis (tercantik) nomor satu di Jepang, maka ia harus mendapatkan calon suami terhebat se-Jepang."

Pada kutipan di atas, tampak kesan dari bagaimana tindakan tokoh lain (tuan tikus) dalam memaknai kecantikan yang dimiliki oleh putrinya, yaitu untuk mencarikannya pasangan yang sepadan dengan nilai tinggi yang dimiliki oleh putrinya tersebut. Dari kutipan ini pula memunculkan implikasi pada penggambaran hubungan seorang ayah dan anak perempuannya, bahwa anak perempuan harus menerima keputusan bapaknya terhadap dirinya, dalam mencarikan pasangan hidupnya sebagai bagian dari peran orang tua terhadap anaknya. Hal ini terlihat saat ayahnya membawa serta istri dan putrinya untuk menemui tuan matahari untuk mengajukan penawaran agar tuan matahari berkenan menikahi putrinya. Berikut ini kutipannya:

そこでおとうさんはおかあさんと娘を連れ て、天へ上っていきました。そしてお日さ まに、「お日さま、お日さま、あなたは世 の中でいちばんえらいお方です。どうぞわ たくしの娘をお嫁にもらって下さいま し。」といって、ていねいにおじぎをしま Lた。

Oleh karena itu, ayah tikus mengajak serta ibu tikus dan anak gadisnya naik menuju langit. Lalu ia berkata pada matahari,"'Tuan Matahari, Tuan Matahari, Engkau adalah yang terhebat di dunia. Perkenankanlah putriku untuk kau ambil menjadi istrimu, "ujar ayah tikus sambil memberi hormat.

Tokoh anak gadis tikus digambarkan sama sekali tidak menunjukkan penolakan atau 
respon apapun terhadap keputusan ayahnya. Karenanya hal ini bisa dijadikan salah satu penggambaran terhadap imaji perempuan dari aspek psikis tokoh ini, yaitu kepatuhan dan penerimaan terhadap keputusan ayahnya.

Dua kutipan di atas selain menjelaskan tentang aspek psikis, juga sekaligus menggambarkan aspek sosial dari tokoh perempuan anak gadis tikus pada cerita ini, yaitu kedudukan perempuan sebagai anak dalam keluarga, yang tidak mendapatkan keleluasaan dalam memilih pasangan hidupnya sendiri dan tidak mempunyai daya dalam menentukan jalan hidupnya sendiri. Ketiadaan ungkapan ekspresi diri/perasaan tokoh perempuan di sepanjang cerita ini memberikan implikasi bahwasanya perasaan perempuan tidaklah menjadi fokus utama, meskipun cerita awalnya berkisah tentang seorang gadis. Selain itu, pada tinjauan aspek sosial, cerita ini memberikan gambaran mengenai imaji perempuan yang tunduk pada peran besar serta kedudukan ayah yang tinggi dalam kehidupannya.

\section{Analisis citraan perempuan pada cerita rakyat Kaguya Hime}

Tokoh utama dalam cerita rakyat ini adalah Kaguya Hime, seorang gadis yang sangat cantik. Karena kecantikannya, ia mendapatkan banyak lamaran dari para pemuda. Aspek psikis yang tergambar pada tokoh Kaguya Hime adalah sosok perempuan yang sungkan dalam menyatakan perasaannya sendiri. Hal ini terlihat dalam kutipan berikut ini:

でも、かぐやひめは、お嫁に行くつもりは ありません。そこでかぐやひめは、困って しまい、「では、私が言う品物を持ってき て下さった方のところへ、お嫁に行きまし よう」と、言って、世にも珍しいと言われ る品物を一人ー人に頼みました。

Tetapi, Kaguya Hime tidak berminat untuk menikah. Oleh karena itu, Kaguya Hime merasa cemas. "Aku akan pergi sebagai pengantin perempuan, ke tempat siapa saja yang berhasil membawa kemari benda-benda yang aku sebutkan." Ujar Kaguya Hime, sambil menyebutkan benda-benda yang aneh sebagai permintaannya kepada masing-masing orang.
Kaguya Hime tidak berani menyatakan penolakannya terhadap lamaran para pemuda tersebut, sehingga ia memilih untuk membuat strategi berupa pengajuan persyaratan yang berat kepada para pemuda tersebut. Dari penggalan ini, tampak imaji perempuan dari tokoh Kaguya Hime yaitu sosok perempuan tidak berani untuk mengungkapkan perasaannya secara langsung dan terbuka. Selain itu, sosok Kaguya Hime juga digambarkan sebagai sosok gadis yang pasrah. Di akhir cerita ini, Kaguya Hime diceritakan harus pulang tempat asalnya yaitu bulan. Citraan perempuan dari aspek psikis tergambar dalam rasa sedih yang Kaguya Hime rasakan karena ia harus berpisah dengan kakek dan nenek yang membesarkannya dengan penuh kasih sayang. Meskipun demikian, ia berpasrah karena ia harus kembali ke negeri asalnya. Berikut ini adalah kutipannya.

それ以来、かぐやひめは毎晚毎晚悲しそう に月を見上げては泣いていました。ある日、 おじいさんとおばあさんが心配してわけを たずねると、かぐや姫は泣きながら言いま した。「実は、わたくしは月の世界のもの です。今まで育てていただきましたが、今 度の満月の夜には月へ帰らなくてはなりま せん」

Sejak saat itu, Kaguya Hime setiap malam menangis sambil menatap bulan dengan sedih. Suatu hari, kakek dan nenek bertanya pada Kaguya Hime karena cemas melihatnya. Kaguya Hime menangis sambal berkata, "Sebenarnya aku adalah penghuni bulan. Hingga saat ini aku dibesarkan oleh kakek dan nenek, tapi malam purnama yang berikutnya aku harus pulang ke bulan."

Penggambaran sosok Kaguya Hime yang sulit untuk mengekpresikan perasaannya secara langsung juga menggambarkan aspek sosial dari tokoh perempuan ini. Terkait dengan kedudukannya sebagai perempuan secara umum dalam masyarakat, yang cenderung untuk menutupi atau tidak menunjukkan perasaannya, serta tidak mengungkapkan isi hati atau opini pribadinya secara langsung dan terbuka. 
Analisis Citraan Perempuan Pada Cerita $\underline{\text { Rakyat Indonesia }}$

\section{Analisis citraan perempuan pada cerita} Putri Pandan Berduri.

Dilihat dari aspek fisiknya, tokoh perempuan dalam cerita ini, Putri Pandan Berduri, direpresentasikan sebagai perempuan yang sangat cantik. Imaji perempuan dari aspek sosial pada tokoh ini adalah sosok anak perempuan yang menjadi bagian dari milik ayahnya, sehingga ayahnya berhak untuk menentukan masa depan anak perempuannya, termasuk dalam pemilihan pasangan hidup

Pada cerita ini, tokoh Putri Pandan Berduri tidak digambarkan secara langsung muncul mengekspresikan dirinya dalam cerita. Oleh karena itu, aspek psikis pada tokoh ini tidak diperoleh melalui penggambaran perasaan yang diungkapkan secara langsung oleh tokoh perempuan, namun melalui implikasi tindakan dari tokoh laki-lakinya, yaitu ayah angkatnya, Batin Lagoi. Dalam cerita ini, sang raja memiliki hak untuk untuk memilihkan pasangan hidup bagi sang putri. Hal ini terlihat saat sang raja mengajukan tawaran untuk menikahkan Jenang Perkasa dengan putri Pandan Berduri. Berikut ini adalah kutipannya.

Usai perjamuan, Batin Lagoi menghampiri Jepang Perkasa. "Wahai Jepang Perkasa! Aku kagum dan terkesan dengan keelokan budi pekertimu. Bersediakah engkau aku nikahkan dengan putriku, Pandan Berduri?" tanya Batin Lagoi. "Dengan segala kerendahan hati, saya bersedia menerima putri tuan sebagai istri saya, " jawab Jenang Perkasa dengan sopannya.

Hal ini memunculkan implikasi berupa penggambaran aspek psikis dari tokoh perempuan, yaitu berupa penerimaan Putri Pandan Berduri terhadap segala keputusan yang telah ditetapkan oleh sang raja terhadap dirinya. Dengan demikian, didapatkan imaji perempuan dari aspek psikis yaitu sebagai sosok anak perempuan yang patuh pada ayahnya, dan mengikuti keputusan ayahnya. Aspek psikis ini berkaitan erat dengan aspek sosial dari tokoh perempuan, yaitu sebagai seorang anak perempuan yang kedudukannya berada di bawah sang ayah. Dengan hubungan yang penuh hierarki tersebut, perempuan hanya dapat bersikap tunduk dan pasrah atas segala ketetapan yang berlaku pada dirinya.

Di akhir cerita, Putri Pandan Berduri digambarkan hidup dengan bahagia bersama dengan Jenang Perkasa, suami pilihan ayahnya. Hal ini juga hendak mengindikasikan nilai positif dari sikap patuh yang dilakukan oleh seorang anak perempuan terhadap keputusan ayahnya, yaitu berupa imbalan kehidupan yang penuh kebahagiaan.

\section{Analisis citraan perempuan pada cerita Putri Mandalika Nyale}

Aspek fisik dari tokoh Putri Mandalika adalah parasnya yang sangat cantik, sehingga diceritakan ia banyak mendapatkan lamaran dari banyak pangeran dari banyak wilayah.

Tampak jelas parasnya yang elok diwariskan dari ibunya Dewi Seranting, sementara tingkah lakunya yang bijak bestari diturunkan dari kearifan Raja Tonjang Beru.

Aspek psikis Putri Mandalika tergambar melalui kutipan di atas, yaitu sosok perempuan yang bijaksana. Sikap bijaksananya ini tampak saat ia diminta untuk memutuskan satu di antara banyak pelamar yang akan menjadi calon suaminya, setelah kedua orang tuanya tidak bisa memutuskan calon suami bagi Putri Mandalika.

Putri Mandalika dengan segala kebijaksanaannya meminta waktu untuk bersemedi. Ia meminta para pangeran dan para putra mahkota untuk bersabar. Putri tidak ingin perang besar berkecamuk di antara semua kerajaan. Putri Mandalika paham, jika perang besar terjadi, maka yang menjadi korban sebenarnya adalah rakyat. Ia tidak pernah melihat perang besar, tapi ia cukup cerdas untuk menghitung akibat yang bisa ditimbulkan sebuah perang. Apalagi perang antar banyak kerajaan.

Selain bijaksana, citraan perempuan dari aspek yang tampak hadir dalam cerita ini adalah sosok perempuan yang cerdas dan berpikir masak-masak sebelum mengambil keputusan. Dari aspek sosial, Putri Mandalika memiliki status sosial yang tinggi karena dirinya adalah seorang putri raja. Ia memiliki kesadaran akan 
kedudukannya tersebut, yang bukan tanpa konsekuensi.

Akhirnya, pada tanggal 20 bulan ke sepuluh penanggalan Sasak, semua putra mahkota dan pangeran beserta seluruh rakyat berduyunduyun menuju Pantai Seger Kuta. Putri Mandalika berdiri di atas sebuah tebing batu. Ia berpesan bahwa ia ingin semua kedamaian dan kesejahteraan tetap lestari di Lombok. Pesannya ditangkap dengan sangat jelas oleh semua yang hadir di sana. Lalu ia juga mengatakan bahwa ia adalah untuk kebahagiaan semua orang. Bukan penyulut kebencian dan amarah. Setelah berpesan demikian ia melompat ke dalam ombak yang bergulung-gulung. Petir menyambar-nyambar dari langit dengan kilat terang benderang. Hujan deras dan gelombang besar menyambut tubuh molek Putri Mandalika. Ia tenggelam ditelan lautan.

Sikap yang ditunjukkan melalui kutipan di atas menggambarkan aspek psikis sekaligus aspek sosial dari Putri Mandalika, bahwa ia merupakan sosok perempuan yang matang dalam berpikir dan rela mengorbankan dirinya. Secara umum, penggambaran aspek psikis dari Putri Mandalika mengarah pada sikap perempuan dengan sosoknya yang berupaya menjalannya perannya dengan sebaik-baiknya. Citraan ini mempunyai hubungan yang erat dengan citraan Putri Mandalika dari aspek sosial budaya, yaitu kedudukan tokoh ini dalam masyarakat, yaitu sebagai seorang putri raja. Ia mempunyai kewajiban untuk bersikap selayaknya seorang putri yang tidak boleh mementingkan kepentingan pribadinya di atas kepentingan rakyat banyak. Ia ditampilkan sebagai seorang perempuan yang merasa berkewajiban untuk menjaga situasi yang kondusif bagi rakyatnya, sehingga ia memutuskan untuk mengorbankan dirinya sebagai ganti bagi kelangsungan kesejahteraan dan kedamaian rakyatnya. Wujudnya dikisahkan menjelma menjadi cacing nyale, yang dapat dikonsumsi dan membawa manfaat yang banyak bagi rakyatnya.

Analisis citraan perempuan pada cerita Pangeran Pande Gelang dan Putri Cadasari Aspek fisik dari tokoh Putri Cadasari (Arum) adalah seorang perempuan muda yang cantik jelita. Citraan perempuan melalui aspek psikis yang ditampilkan adalah sosok seorang perempuan sosoknya yang sopan dan lembut hati pun tergambar dalam cerita ini.

"Maafkan saya," pinta sang Putri. "Bukan maksud saya menyinggung perasaan Kisanak, apalagi menganggap rendah."

Selain itu, ia pun digambarkan sebagai sosok perempuan yang berputus asa dan lemah tak berdaya karena ia tidak kuasa menolak permintaan pangeran Cunihin yang hendak memperistrinya. Ia takut kepada Pangeran Cunihin, karena meskipun tampan, Pangeran Cunihin adalah seorang yang kejam, bengis dan berilmu tinggi. Putri Cadasari (Arum) pasrah atas nasib yang sedang dialaminya, dan mengharapkan pertolongan datang dari seorang pemuda yang muncul dalam petunjuk (wangsit) yang diperolehnya.

...Namun penantian ini hampir sia-sia. Tiga hari lagi Pangeran Cunihin akan datang dan memaksa saya kawin dengannya. Barangkali ini sudah suratan takdir saya, Ki,...

Putri Cadasari (Arum) digambarkan sebagai sosok yang penuh kepasrahan tanpa ada suatu apapun yang dapat dilakukan. Sosok yang merasa inferior terhadap kuasa pihak lain terhadap dirinya, sehingga ia merasa lemah di hadapan kuasa pihak lain tersebut. Meski ia membenci Pangeran Cunihin, Putri Cadasari (Arum) tidak sanggup memberikan penolakan terhadap keinginan Pangeran Cunihin.

"Apa Aki sudah gila? Bagaimana saya mau dipersunting lelaki yang sangat saya benci?" sergah Putri Arum dengan wajah memerah.

Dari aspek sosial, Putri Cadasari adalah sosok perempuan yang berkedudukan tinggi karena status sosialnya sebagai seorang putri raja.

\section{Analisis Komparatif Cerita Rakyat Indonesia dan Cerita Rakyat Jepang}

Dari analisis citraan perempuan terhadap tiga cerita rakyat Jepang dan tiga cerita rakyat Indonesia di atas, terdapat persamaan pada citraan perempuan baik pada cerita rakyat Jepang dan Indonesia dalam aspek fisik yaitu penggambaran tokoh perempuan sebagai gadis muda yang cantik jelita. Terdapat sedikit perbedaan antara penggambaran psikologis tokoh perempuan pada cerita rakyat Jepang dan Indonesia, yaitu pada cerita rakyat Jepang, tokoh perempuannya tidak mengekspresikan 
atau mengungkapkan keinginan pribadinya, seperti yang ada pada cerita rakyat Kaguya Hime yang memendam perasaannya yang enggan untuk menikah, sedangkan pada cerita rakyat Pangeran Pande Gelang dan Putri Cadasari, tokoh perempuannya masih digambarkan mengutarakan isi hatinya pada tokoh lain mengenai ketidakinginannya untuk dinikahi oleh Pangeran Cunihin, meskipun ia merasa tak berdaya untuk dapat mewujudkan keinginannya tersebut. Penggambaran kebahagiaan yang diraih tokoh perempuan juga bertolak dari keputusan pihak lain. Seperti yang terdapat dalam cerita rakyat Nezumi no Yomeiri dan Putri Pandan Berduri yang diceritakan berakhir bahagia setelah dinikahkan dengan lelaki pilihan ayah masing-masing.

Sedangkan pada tipe cerita yang berakhir dengan pengorbanan diri, tokoh perempuannya mengambil keputusan yang didasarkan atas pertimbangan tanggung jawab yang diembannya sebagai bagian dari komunitas/masyarakatnya. Hal ini terlihat pada cerita rakyat Kurohime to Kokuryuu, Kaguya Hime dan Putri Mandalika Nyale. Secara umum, citraan perempuan yang tergambar baik pada cerita rakyat Jepang dan Indonesia memiliki persamaan pada aspek psikologis berupa kepasrahan.

Aspek sosial tokoh-tokoh perempuan dari cerita rakyat kedua negara memiliki kesamaan, yaitu tokoh perempuan muda yang memiliki latar sosial yang beragam, baik dari kalangan biasa maupun dari kalangan bangsawan (putri raja). Tokoh-tokoh perempuan digambarkan menjalankan peran dan tanggung jawabnya masing-masing sesuai dengan latar belakang serta status sosialnya.

\section{KESIMPULAN DAN SARAN}

Dari tiga cerita rakyat Indonesia (Putri Mandalika Nyale, Putri Pandan Berduri, dan Pangeran Pande Gelang dan Putri Cadasari) dan tiga cerita rakyat Jepang di atas (Nezumi no Yomeiri, Kuro Hime to Kokuryuu, dan Kaguya Hime), terdapat kesamaan yaitu pada citra perempuan dari aspek fisik, yaitu berupa sosok gadis muda yang cantik. Selain itu, terdapat kemiripan pada citra perempuan dari aspek psikis yaitu sosok tokoh perempuan yang tunduk patuh, rela mengorbankan kepentingan dirinya, dan pasrah pada nasibnya. Nasib para tokoh perempuan yang dimaksud adalah berkaitan dengan citra tokoh-tokoh perempuannya dari aspek sosialnya yaitu sosok perempuan dalam beragam kedudukannya serta perannya. Kesemua tokoh perempuannya digambarkan sebagai sosok yang menjalankan peran dan tanggung jawab dalam kedudukannya berdasarkan aspek sosial masing-masing tokoh perempuan. Latar belakang budaya patriarkat pada masyarakat Indonesia dan Jepang juga disinyalir memberikan pengaruh terhadap citra perempuan yang ditampilkan dalam ceritacerita rakyat tersebut.

\section{DAFTAR PUSTAKA}

[1] S.Djajanegara, Kritik Sastra Feminis: Sebuah Pengantar, Jakarta: PT Gramedia Pustaka Utama., 2000.

[2] Sugihastuti dan Suharto, Kritik Sastra Feminis: Teori dan Aplikasinya, Yogyakarta: Pustaka Pelajar, 2005.

[3] S.D. Damono, Pegangan Penelitan Sastra Bandingan, Jakarta: Pusat Bahasa, 2005.

[4] J.Danandjaja, Folklor Indonesia: Ilmu Gosip, Dongeng, dan lain-lain, Jakarta: Grafiti, 2002.

[5] S. Endraswara, Metodologi Penelitian Folklor, Yogyakarta: Media Pressindo, 2009.

[6] N. K. Ratna, Penelitian Sastra: Teori, Metode, dan Teknik. Yogyakarta: Pustaka Pelajar. 2004.

[7] K.K.Ruthven, Feminist Literary Study: An Introduction. Cambridge University Press. 1984.

[8] P.R. Tong, Feminist Thought: Pengantar Paling Komprehensif kepada Arus Utama Pemikiran Feminis terjemahan oleh Aquarini P. Prabasmoro, Yogyakarta: Jalasutra. 2009.

[9] R. Wellek dan W. Austin. Teori Kesusastraan (terj. Melani Budianta). Jakarta: PT Gramedia. 1989.

[10] D. Wijayanti, Buku Cerita Rakyat Indonesia Super Lengkap 33 Propinsi, Yogyakarta: New Diglossia, 2011 